\title{
Which rhizobia nodulate which legumes in New Zealand soils?
}

\author{
M. ANDREWS, D. JACK, D. DASH and S. BROWN \\ Faculty of Agriculture and Life Sciences, Lincoln University, Lincoln 7647, Christchurch \\ mitchell.andrews@lincoln.ac.nz
}

\begin{abstract}
Recent work which genotypically characterised rhizobia of native, crop and weed legumes in New Zealand and examined their cross-nodulation ability is reviewed and related to earlier work with focus on New Zealand pasture systems. The New Zealand native legumes were exclusively effectively nodulated by novel strains of Mesorhizobium which did not nodulate crop or weed legumes. Clovers, lucerne, Lotus and grain legumes were effectively nodulated by different genera, species and biovars of rhizobia primarily originating from inoculum. Rhizobial symbionts of white clover have established over wide areas in New Zealand. Weed legumes are effectively nodulated by different genera/ species of rhizobia depending on species. Bradyrhizobia that cross-nodulate lupins, gorse, European broom and tagasaste are widespread in New Zealand.
\end{abstract}

Keywords: Bradyrhizobium, Burkholderia, Ensifer, Mesorhizobium, Rhizobium

\section{Introduction}

Most legume species can obtain a substantial amount of their nitrogen $(\mathrm{N})$ requirements for growth from symbiotic bacteria (general term rhizobia) in root nodules and this can give them an advantage in low $\mathrm{N}$ soils if other factors are favourable for growth (Andrews et al. 2011, 2013). There are only four genera of native legumes on the main New Zealand islands. These are Carmichaelia (New Zealand broom), Clianthus (kakabeak), Montigena (scree pea) and Sophora (kowhai) (Wagstaff et al. 1999; Heenan 2000; Heenan et al. 2001). However, over the past 150 years, several legumes have become important crop plants in New Zealand agricultural systems with clovers (Trifolium spp.), lucerne (Medicago sativa) and Lotus spp. of greatest importance in pasture systems. Also, over 100 legume species from different continents have become naturalised in New Zealand and gorse (Ulex europaeus), in particular, is a major weed in high country systems (Popay et al. 2010).

A wide range of bacteria have been shown to form $\mathrm{N}_{2}$ fixing nodules on legumes (Sprent 2009). Some legumes are highly specific in their rhizobial symbionts while others are nodulated by diverse rhizobia. Also, some rhizobia can form "ineffective" nodules on some legumes; these nodules do not fix atmospheric $\mathrm{N}_{2}$. Rhizobial symbionts of the common legume crops are not native to New Zealand and specific rhizobial inoculants have been used extensively in New Zealand to produce high $\mathrm{N}_{2}$ fixing crop plants (Greenwood \& Pankhurst 1976). In the 1960s and 1970s, considerable work was carried out characterising the rhizobia associated with a range of legumes occurring in New Zealand. This work primarily classified rhizobia in relation to their growth rate on artificial medium and their ability to form nodules on different groups of legumes (Greenwood \& Pankhurst 1976). However, rhizobia can now be precisely distinguished and characterised on the basis of their DNA (genotypic characterisation; Willems 2006). Here we review recent work which genotypically characterised rhizobia of native, crop and weed legumes in New Zealand and examined their cross-nodulation ability. Findings are related to earlier work with a focus on New Zealand pasture systems.

\section{Sources of data}

The literature was reviewed and all work which characterised rhizobial isolates from legumes in New Zealand on the basis of their gene sequences was considered. In addition, rhizobial strains currently recommended for use on crop plants in New Zealand by the International Collection of Microorganisms from Plants (ICMP), Landcare Research, Auckland, New Zealand are summarised. Findings are considered in relation to earlier work which characterised rhizobia primarily on the basis of their growth rate and host legume(s).

\section{Rhizobia in New Zealand soils}

The New Zealand native legumes were exclusively effectively nodulated by novel strains of Mesorhizobium (Weir et al. 2004; Tan et al. 2012, 2013, 2015). The New Zealand brooms and kowhai were nodulated by two separate groups of Mesorhizobium strains. However, all strains which nodulated New Zealand brooms and almost all strains which nodulated kowhai, could nodulate kakabeak (Weir 2006; Tan 2015). Crow et al. (1981) reported that rhizobial symbionts of native brooms did not nodulate a range of clovers. Recent work has shown that selected strains from New Zealand brooms and kowhai did not nodulate white clover ( $T$. repens), red clover (T. pratense), subterranean clover (T. subterraneum), lucerne, Lotus pedunculatus, field pea (Pisum sativum), field bean (Vicia faba), Lupinus 
polyphyllus, blue lupin (L. angustifolius), white lupin (L. albus), tree lupin (L. arboreus), gorse or any of the weed species listed in Table 2 except for Robinia pseudoacacia (Liu 2014; Andrews M. \& Tan H.W. unpublished data). All strains tested produced nonfunctional nodules on Robinia pseudoacacia (Liu 2014).

Rhizobium leguminosarum bv. trifolii is the ICMP recommended inoculum for white clover, red clover, subterranean clover, alsike clover (T. hybridum) and Caucasian clover (T. ambiguum), although subterranean clover and Caucasian clover each need specific strains different from those for the other clovers (Table 1; Greenwood \& Pankhurst 1976; Landcare Research 2015). Also, there are different recommended strains for diploid, tetraploid and hexaploid Caucasian clover (Patrick et al. 1994; Landcare Research 2015). Strains of $R$. leguminosarum bv. trifolii for white clover have become established over wide areas in New Zealand to the extent that in these areas there is now likely to be little or no advantage in using inoculum on white clover crops (Lowther \& Kerr 2011). Some strains of $R$. leguminosarum bv. trifolii can produce non-functional nodules on kowhai and New Zealand brooms (Crow et al. 1981; Weir 2006; Tan 2015). Indeed, these strains are commonly isolated from native legumes growing under natural conditions emphasising how widespread these strains are. Rhizobium leguminosarum bv. viciae is the ICMP recommended inoculum for field pea (Pisum sativum), field bean (Vicia faba), lentil (Lens culinaris) and vetch (Vicia sativa) and it is likely that in areas where this inoculum has been used extensively, there will be no effect from further additions. This is the case for field pea on the Lincoln University farm (Nguyen 2012). Some strains of R. leguminosarum bv. viciae can produce functional nodules on white clover (Weir 2006) but it is not known how effective these are in promoting growth. Rhizobium leguminosarum bv. viciae has also been found to nodulate the weed vetches Vicia hirsuta and $V$. disperma in New Zealand soils (Liu 2014).

Ensifer meliloti is the ICMP recommended inoculum for lucerne and it is required when sowing lucerne into soil with no history of this crop (Black \& Moot 2013). Also, it has been reported in earlier work that lucerne rhizobial strains are less persistent than clover strains in acid soils so they may have difficulty establishing in some New Zealand soils (Greenwood \& Pankhurst 1976). Ensifer meliloti produces high rates of $\mathrm{N}_{2}$ fixation on lucerne. However, lucerne can also be nodulated by different strains of Rhizobium in New Zealand soils (Wigley et al. 2015). Under controlled conditions, growth of lucerne was substantially greater with Ensifer meliloti than with these Rhizobium strains (Liu 2014). This indicates that the effectiveness of Ensifer meliloti inoculum could be reduced in soils with high populations of these Rhizobium strains. It is not known how widespread these Rhizobium strains are. Ensifer meliloti also nodulates King Island melilot (Melilotus indicus) in New Zealand (Liu 2014).

Table 1 Rhizobial genera, species, biovars and strains shown to nodulate legume crop plants in New Zealand soils

\begin{tabular}{lcc}
\hline Legume & Rhizobia & Reference \\
\hline Clovers (Trifolium spp.) & Rhizobium leguminosarum bv. trifolii & ICMP recommended inoculum; Tan 2015 \\
\hline Lucerne (Medicago sativa) & $\begin{array}{c}\text { Ensifer meliloti } \\
\text { Rhizobium }\end{array}$ & ICMP recommended inoculum; Liu 2014; \\
\hline Lotus pedunculatus & Bradyrhizobium ICMP 5798, & Wigley et al. 2015 \\
& Bradyrhizobium ICMP 5942 & Bradyrhizobium \\
Lotus corniculatus & Mesorhizobium loti & ICMP recommended \\
& inocula \\
Lupins & Bradyrhizobium ICMP 8377 2014 \\
(Lupinus spp.) & Bradyrhizobium & ICMP recommended \\
& & inoculum \\
& & ICMP recommended \\
inoculum
\end{tabular}

Lupinus polyphyllus

Field pea (Pisum sativum)

Soybean (Glycine max)

Rhizobium leguminosarum bv. viciae

Ryan-Salter et al. 2014 
Bradyrhizobium strains ICMP 5798 and ICMP 5942 are the recommended rhizobial inoculants for diploid and tetraploid Lotus pedunculatus including cv. Maku while Mesorhizobium loti is the ICMP recommended inoculum for Lotus corniculatus and serradella (Ornithopus sativus). Mesorhizobium loti is also recommended for "crop lupins" although all rhizobial isolates from lupins growing in New Zealand were found to be strains of Bradyrhizobium (Tables 1, 2; Ryan-Salter et al. 2014; Liu 2014) and the effectiveness of $M$. loti on lupins needs testing. Bradyrhizobium ICMP 8377 is also a recommended inoculum for serradella and crop lupins. The 'Group G' commercial inoculant recommended for annual lupins in New Zealand by BASF, Auckland, New Zealand, is a Bradyrhizobium that effectively nodulates Lupinus polyphyllus (Liu 2014). However, bradyrhizobia that nodulate L. polyphyllus are present across a wide range of sites in the South Island including the agricultural stand of L. polyphyllus at Sawdon Station, Lake Tekapo, which was established using uninoculated seed (RyanSalter et al. 2014). This is in agreement with Scott (1989) who stated that L. polyphyllus will nodulate in high country soil without inoculum although it was also indicated that use of inoculum could be beneficial.

A diverse range of rhizobia genera nodulated weed legumes in New Zealand soils depending on plant species: these rhizobia differed from those of New Zealand native legumes and of the major crops
(Tables 1, 2). Selected rhizobial strains from all weed species listed in Table 2 did not nodulate Carmichaelia australis, Clianthus puniceus or Sophora microphylla (Weir 2006; Liu 2014). All weed legumes were nodulated by rhizobia in a single genus except the South African native Dipogon lignosus which was nodulated by Bradyrhizobium, Rhizobium and Burkholderia strains (Liu et al. 2014). Sequence data indicated that the Bradyrhizobium and Rhizobium strains were respectively Bradyrhizobium japonicum and Rhizobium leguminosarum and it is likely that both strains were derived from crop inoculum (Table 1; Liu et al. 2014). Gene sequences for the Burkholderia strains indicated that they originated in South Africa and were somehow transported with $D$. lignosus from their native habitat into New Zealand (Liu et al. 2014). This was the first report of a Burkholderia-rhizobia in New Zealand soils.

Goats rue (Galega officinalis) and sulla (Hedysarum coronarium) are highly specific in their rhizobial symbionts and were nodulated by $R$. galegae and $R$. sullae respectively as has been reported previously for these plants sampled outside New Zealand (Liu et al. 2012). Sulla has been considered as a potential forage legume in New Zealand as it provides high quality, non-bloating feed (Krishna et al. 1990; Minneé et al. 2004). This plant would need a highly specific rhizobial inoculant in New Zealand. Robinia pseudoacacia and dally pine (Psoralea pinnata) were nodulated by Mesorhizobium strains which were different from the

Table 2 Rhizobial genera and species shown to nodulate weed legumes in New Zealand soils

\begin{tabular}{llc}
\hline Legume & Rhizobia & Reference \\
\hline Dipogon lignosus & $\begin{array}{c}\text { Bradyrhizobium japonicum } \\
\text { Rhizobium leguminosarum } \\
\text { Burkholderia }\end{array}$ & Liu et. 2014 \\
\hline Goats rue (Galega officinalis) & Rhizobium galegae & Liu et al. 2012 \\
\hline Sulla (Hedysarum coronarium) 2012 \\
\hline Robinia pseudoacacia & Rhizobium sullae & Liu 2014 \\
\hline Dally pine (Psoralea pinnata) & Mesorhizobium & Liu 2014 \\
\hline Wild serradella (Ornithopus pinnatus) & Mesorhizobium & Weir 2006; Liu 2014) \\
\hline Wattles (Acacia spp.) & Bradyrhizobium & Liu 2014; Black et al. 2015; \\
\hline Tree lupin (Lupinus arboreus) & Bradyrhizobium & Weir 2006; Liu 2014; Black et al. 2015 \\
\hline Gorse (Ulex europaeus) & Bradyrhizobium & Weir 2006; Liu 2014; Black et al. 2015 \\
\hline European broom (Cytisus scoparius) & Bradyrhizobium & Liu 2014; Black et al. 2015 \\
\hline Tagasaste (Chamaecytisus palmensis) & Bradyrhizobium & Bradyrhizobium \\
\hline
\end{tabular}


Mesorhizobium strains of New Zealand native legumes. Bradyrhizobium nodulated wild serradella (Ornithopus pinnatus), Acacia spp. (A. dealbata, A. longifolia), tree lupin (L. arboreus), gorse, European broom and tagasaste (Chamaecytisus palmensis). This is in agreement with earlier reports that serradella, lupin, gorse and European broom are normally nodulated by slow growing rhizobial strains in New Zealand (Greenwood \& Pankhurst 1976). Wild seradella and Acacia only formed effective nodules with specific strains but tree lupin, gorse, European broom and tagasaste formed effective nodules with Bradyrhizobium strains from all legume species (Liu 2014). Bradyrhizobium that cross-nodulate Lupinus polyphyllus, tree lupin, gorse, European broom and tagasaste are widespread in New Zealand (Weir et al. 2004; Weir 2006; Liu 2014; Ryan-Salter et al. 2014; Black et al. 2015). A group of these rhizobia have some unique gene sequences and may be of New Zealand origin (Ryan-Salter et al. 2014). If this proves to be the case, it could in part explain the success of these plants as weed species in New Zealand. Also, any inoculum used on Lupinus polyphyllus is likely to nodulate gorse, European broom, tree lupin and tagasaste.

\section{Conclusions}

A diverse range of rhizobia genera and species nodulate legumes in New Zealand soils. It seems likely that further rhizobia will be associated with the many naturalised legumes still to be examined. Generally, native, crop and weed legumes are nodulated by different groups of rhizobia with crop legumes primarily effectively nodulated by rhizobia used as inoculum. However, lucerne can be nodulated by Rhizobium strains which give poor growth. It is not known how widespread these strains are and this warrants further study. Also, further work is required to assess the level of persistence of lucerne rhizobial inoculants in different soils in New Zealand. Bradyrhizobia that cross-nodulate lupins, gorse, European broom and tagasaste are of widespread occurrence in New Zealand and these require further characterisation. Also, further work is required to fully assess if Lupinus polyphyllus benefits from rhizobial inoculants in high country soils in the South Island..

\section{ACKNOWLEDGMENTS}

We thank the two anonymous referees whose suggested changes and additions substantially improved the paper.

\section{REFERENCES}

Andrews, M.; James, E.K.; Sprent, J.I.; Boddey, R.M.; Gross, E.; dos Reis Jr, F.B. 2011. Nitrogen fixation in legumes and actinorhizal plants in natural ecosystems: values obtained using ${ }^{15} \mathrm{~N}$ natural abundance. Plant Ecology \& Diversity 4: 131-140.
Andrews, M.; Raven, J.A.; Lea, P.J. 2013. Do plants need nitrate? The mechanisms by which nitrogen form affects plants. Annals of Applied Biology 163: 174-199.

Black, A.D.; Ryan-Salter, T.P.; Liu, W.Y.Y.; Moot, D.J.; Hill, G.D.; Andrews, M. 2015. Bradyrhizobia with a distinct nodA gene nodulate Lupinus polyphyllus in New Zealand soils. Pp. 45. In: Proceedings of the XIV International Lupin Conference, Milan, Italy.

Black, D.B.S.; Moot, D.J. 2013. Autumn establishment of lucerne (Medicago sativa L.) inoculated with four different carriers of Ensifer meliloti at four sowing dates. Proceedings of the New Zealand Grassland Association 75: 137-144.

Crow, V.L.; Jarvis, B.D.W.; Greenwood, R.M. 1981. Deoxyribonucleic acid homologies among acidproducing strains of Rhizobium. International Journal of Systematic Bacteriology 31: 152-172.

Greenwood, R.M., Pankhurst, C.E. 1976. The Rhizobium component of the nitrogen-fixing symbiosis. Proceedings of the New Zealand Grassland Association 38: 167-174.

Heenan, P.B. 2000. Clianthus (Fabaceae), in New Zealand: a reappraisal of Colenso's taxonomy. New Zealand Journal of Botany 38: 361-371.

Heenan, P.B.; de Lange, P.J.; Wilton, A.D. 2001. Sophora (Fabaceae) in New Zealand: taxonomy, distribution, and biogeography. New Zealand Journal of Botany 39: 17-53.

Krishna, H.; Kemp, P.D.; Newton, S.D. 1990. 'Necton' sulla - A preliminary agronomic evaluation. Proceedings of the New Zealand Grassland Association 52: 157-159.

Landcare Research. 2015. http://www.landcareresearch. co.nz/resources/collections/icmp/current-rhizobiumstrain-recommendations

Liu, W.Y.Y. 2014. Characterisation of rhizobia and studies on $\mathrm{N}_{2}$ fixation of common weed legumes in New Zealand. PhD thesis. Lincoln University, New Zealand.

Liu, W.Y.Y.; Ridgway, H.J.; James, T.K.; James, E.K.; Chen, W-M.; Sprent, J.I.; Young, J.P.W.; Andrews, M. 2014. Burkholderia sp. induces functional nodules on the South African invasive legume Dipogon lignosus (Phaseoleae) in New Zealand soils. Microbial Ecology 68: 542-555.

Liu, W.Y.Y.; Ridgway, H.J.; James, T.K.; Premaratne, M.; Andrews, M. 2012. Characterisation of rhizobia nodulating Galega officinalis (goat's rue) and Hedysarum coronarium (sulla). New Zealand Plant Protection 65: 192-196.

Lowther, W.L.; Kerr, G.A. 2011. White clover seed inoculation and coating in New Zealand. Proceedings of the New Zealand Grassland Association 73: 93102. 
Minneé, E.M.K.; Bluett, S.J.; Woodward, S.L. 2004. Harvesting sulla for yield and quality. Agronomy N.Z. 34: 83-88.

Nguyen, T.D. 2012. Growth and development of peas in response to different inoculation methods and sowing dates. MAgrSc thesis. Lincoln University, New Zealand.

Patrick, H.N.; Lowther, W.L.; Trainor, K.D. 1994. Inoculation for successful establishment of Caucasian clover. Proceedings of the New Zealand Grassland Association 56: 101-105.

Popay, I.; Champion, P.; James, T. 2010. Common weeds of New Zealand. Plant Protection Inc., Christchurch. 416 pp.

Ryan-Salter, T.P.; Black, A.D.; Andrews, M.; Moot, D.J. 2014. Identification and effectiveness of rhizobial strains that nodulate Lupinus polyphyllus.

Proceedings of the New Zealand Grassland Association 76: 61-66.

Scott, D. 1989. Perennial or Russell lupin: a potential high country pasture legume. Proceedings of the New Zealand Grassland Association 50: 203-206.

Sprent, J.I. 2009. Legume nodulation: a global perspective. Wiley-Blackwell, New Delhi. 183 pp.

Tan, H.W. 2015. Characterisation of rhizobia associated with New Zealand native legumes (Fabaceae) and a study of nitrogen assimilation in Sophora microphylla. PhD thesis. Lincoln University, New Zealand.

Tan, H.W.; Heenan, P.B.; De Meyer, S.E.; Willems, A.; Andrews, M. 2015. Diverse novel mesorhizobia nodulate New Zealand native Sophora species. Systematic and Applied Microbiology 38: 91-98.
Tan, H.W.; Heenan, P.B.; Ridgway, H.J.; Andrews, M. 2013. The New Zealand alpine endemic Montigena novae-zelandiae (Fabaceae) shares rhizobial symbionts with Carmichaelia and Clianthus. New Zealand Journal of Botany 51: 297-307.

Tan, H.W.; Weir, B.S.; Carter, N.; Heenan, P.B.; Ridgway, H.J.; James, E.K.; Sprent, J.I.; Young, J.P.Y.; Andrews, M. 2012. Rhizobia with $16 \mathrm{~S}$ rRNA and nifH similar to Mesorhizobium huakuii but novel recA, gln11, nodA and nodC genes are symbionts of New Zealand Carmichaelinae. PLoS One 7 (10); e47677.

Wagstaff, S.J.; Heenan, P.B.; Sanderson, M.J. 1999. Classification, origins and patterns of diversification in New Zealand Carmichaelinae (Fabaceae). American Journal of Botany 86: 1346-1356.

Weir, B.S. 2006. Systematics, specificity and ecology of New Zealand rhizobia. PhD Thesis. University of Auckland, New Zealand.

Weir, B.S.; Turner, S.J.; Silvester, W.B.; Park, D-C.; Young, J.M. 2004. Unexpectedly diverse Mesorhizobium strains and Rhizobium leguminosarum nodulate native legume genera of New Zealand, while introduced legume weeds are nodulated by Bradyrhizobium species. Applied and Environmental Microbiology 70: 5980-5987.

Wigley, K.; Liu, W.Y.Y.; Khumalo, Q.; Moot, D.J.; Brown, D.S.; Ridgway, H.J. 2015. Effectiveness of three inoculation methods for lucerne (Medicago sativa L.) in two Canterbury soils. New Zealand Journal of Agricultural Research 58: 292-301 http:// dx.doi.org/10.1080/00288233.2015.1028652.

Willems, A. 2006. The taxonomy of rhizobia: an overview. Plant and Soil 287: 3-14, 
